\title{
Exploring How Nigerian Women Foster Action to Be Taken to Involve More Women Participation in Technical and Vocational Education
}

\author{
Robert Akor (Corresponding author) \\ Faculty of Educational Studies, Universiti Putra Malaysia, 43400 UPM, Serdang, Selengor, Malaysia \\ E-mail: robertakor43@yahoo.com \\ Ab Rahim Bin Bakar \\ Faculty of Educational Studies, Universiti Putra Malaysia, 43400 UPM, Serdang, Selengor, Malaysia \\ Azim B.Hj Hamzah \\ Faculty of Educational Studies, Universiti Putra Malaysia, 43400 UPM, Serdang, Selengor, Malaysia \\ Abdullah Bin Mat Rashid \\ Faculty of Educational Studies, Universiti Putra Malaysia, 43400 UPM, Serdang, Selengor, Malaysia
}

Received: 12-12- 2014

doi:10.7575/aiac.ijels.v.3n.1p.14
Accepted: 27-01-2015

URL: http://dx.doi.org/10.7575/aiac.ijels.v.3n.1p.14
Published: $30-01-2015$

\begin{abstract}
Despite the documented benefits to economic and social development of women and the constitutional guarantee for equal right under the law to all citizens, the advancement of the status of women in Nigeria is still far from satisfactory. The participation of women in technical and vocational education is abysmally low. Recent literature describing education of women in technical and vocational education in Nigeria, still need more equality of access to the program. As the Nigerian transition to knowledge economy, information age and vision 20:2020 technologically literate workforce is vital. Likewise the contribution of women to technical and vocational education profession in vital, yet the number of women considering entering historically dominated profession remain at unacceptable level. Employment prospects for women have increased dramatically in the late $20^{\text {th }}$ century. Yet in technical and vocational education profession, a profession that holds promise and opportunity for one to positively impact society-the lack of women in the field seems baffling. In order to examine how Nigerian women foster action to be taken to resolve misrepresentation of women in technical and vocational education in Polytechnic institution a study was important. The purpose of this study was to identify action to be taken so that more women can participate in the program from the perspective of women who are currently enrolled in technical and vocational education program in Polytechnic institution. One major Polytechnic was selected with twelve participants. The descriptive and exploratory research analyzed the interview responses of the participants in order to examine their perceptions. Recommendations made as a result of this study include: a need to formulate specific strategies, policy and program to promote women participation in technical and vocational education, women representation in policymaking bodies; increase number of women lecturers; encourage women to participate in traditionally male dominated technical and vocational fields; conduct nontraditional student support groups and peer counseling; provide nontraditional role model and give preference to female student with regards to recruitment.
\end{abstract}

Key words: women, technical and vocational education, workforce and economy

\section{Introduction}

Despite the documented benefits to economic and social development of women and the constitutional guarantee for equal right under the law to all citizens, the advancement of the status of women in Nigeria is still far from satisfactory. The participation of women in technical and vocational education is abysmally low. Recent literature describing education of women in technical and vocational education in Nigeria, still need more equality of access to the program. As the Nigerian transition to knowledge economy, information age and vision 20:2020 technologically literate workforce is vital. Likewise the contribution of women to technical and vocational education profession in vital, yet the number of women considering entering the historically dominated profession remain at unacceptable level. Employment prospects for women have increased dramatically in the late $20^{\text {th }}$ century. Yet in technical and vocational education profession, a profession that holds promise and opportunity for one to positively impact society-the lack of women in the field seems baffling. In the development of nations, science and technology plays a vital role. There is no doubt that the development of any nation hinges on the social and economic contribution of her citizens. Technical and vocational education in countries across the globe is the pivotal of any national development. It is when the individual in the micro setting are self-reliant that the micro economy becomes buoyant and therefore, technical and vocational 
education is the live wire of technology. According to Uwaifo (2009), it is no exaggeration to assert that technical and vocational education constitutes the arteries that supply the life-sustaining blood through the system on country economy and standard of living. It will be impossible task therefore to plan and develop any economy in which technical and vocational education is not developed. It should be known that such development depends on the education and training given not only to men but also to women. Women form an indispensable part of human resources for development of any society. Without their contribution, the economy of any community or nation will maintain a low level and therefore will not be able to meet global competition. Prominent economist and educational leaders have argued that citizens must become technologically literate to maintain economic growth (Weber \& Custer, 2005). Edu \& Edu (2012) stated that it has been proved beyond reasonable doubt that for any nation to make giant stride in development, women have to move out of their marginalized position.

Over the past decades women are limited in the participation in technical and vocational education programs in institutions of higher learning in Nigeria and this have been a concern to the government. Women today constitute half the population in Nigeria yet they are not well represented in technical and vocational education programs in Polytechnic institutions where skills for economic development are a priority. The importance of women in technical and vocational education has long been recognized. Not only will the increase in women participation in technical and vocational education promote diversity and enhance innovative power, but it also impact the education and career development of future generation. Among major contemporary socioeconomic problems faced by developing countries and Nigeria in particular is unemployment, especially of women and young people. International capital mobility and structural shift in local labor markets have brought discussions of training skill acquisition and workforce development to the forefront of policy dialogues around the world (Rodgers et al., 2006). Nigeria been a developing country needs more technicians to develop her economy. The women must be fully involved and can never be ignored in any meaningful development.

Globalization has brought new challenges for developing economies and the labor markets. To face these challenges, it is important to be competitive in the world market, which to a large extent is driven by scientific and technological innovations. Education and training requires to be made need-oriented, multi-skill and flexible to meet changing needs of the local industry and oversea demands (Kazmi, 2007). Jobs in the coming years will demand higher levels of competencies and skills whilst competencies and skill requirements of existing jobs will continue to grow at a rapid pace, knowledge, skills and talent of workforce provide a competitive edge for individuals as well as entrepreneurs in an ever-changing work environment (Uwaifo, 2009). There is a clear recognition now that human skills would play an important role in sustaining the current pace of growth through enhanced productivity of human capital. Education of women in technical and vocational education is necessary to meet these challenges (Kazmi, 2007).

\section{Research Purpose}

Much of the existing data on women in technical and vocational education or nontraditional programs in Nigeria have been informed by research from the science field. A review of related studies shows lack of qualitative research on the misrepresentation of women in technical and vocational education program. According to Raghuram (2008) researchers have not given attention to the study of women in male-dominated occupation. Most studies focus on women in context-specific male-dominated professions like civil engineering, quantity surveying etc. from a predominantly quantitative perspective. Franks et al., (2006) conducted a qualitative inquiry into the life-role construction of career-oriented women and emphasized specifically the need for more in-depth qualitative work on why women are misrepresented in male-dominated occupation. A qualitative approach as to how Nigerian women foster action to be taken to involve more women participation in technical and vocational education may contribute to the understanding of the factors that inhibit women's access to and participation in this field. Understanding the challenges women in this field encounter will enable the researcher to make suggestions that will improve the access to and participation of women in this field.

\section{Literature Review}

The provision of educational opportunities for women has been an important part of national endeavor in Nigeria since independence. Though these endeavors did yield important results, gender disparity persist with uncompromising tenacity, more in the TVE fields. This is not only a matter of national anxiety and concern but also an issue of national conscience. It is with this concern that the literature put forward some recommendations to attract women into technical and vocational education and other technical related fields.

Women in STEM and technical related fields perceive that they must exert greater amount of efforts than men to succeed and this results are in part is due to male dominated nature of the field (Aronson et al., 2002). Women feel isolated in the field of TVE and other nontraditional programs due to the attitude and action of minority of men within the profession who hold outdated view (Haynie 111, 2003). However, by assuring women that everyone has to expend a lot of efforts appear to make them feel more optimistic about their prospects of these fields.

Women have been made to believe that they cannot do well in math which is a core or foundation for technical and vocational education career. Research has suggested that normalizing efforts-emphasizing that everyone has to achieve success resulted in the high self reported feeling of belonging and future interest in this field. Aronson et al., (2002) stress that STEM practioners should discuss with each other (and with their students) about the struggle and efforts it takes to succeed in STEM fields. According to these authors, emphasizing efforts (as opposed to innate talent) can lead 
to a better objective performance outcome (Haynie 111, 2003). Haynie 111 (2003) also maintain that men/boys should be careful to avoid saying things which call attention to the gender of female students or colleagues and to only emphasize the abilities and attributes which make all people valuable within the profession.

Dar-Nimrod \& Heine (2006) posits that exposure of females to information that differences in math's performance are not a result of stereotypes (is natural talent) can lead to better objective performance, but when told nothing at all, women assume that gender differences, women's math ability are as a result of lack of 'growth' incremental theory of intelligence input of what makes a good mathematician, the negative performance effect of stereotypes threat can be offset (Aronson et al., 2002; Good et al., 2012). Some researchers indicate that highly feminist (girl y') STEM role models can actually decrease non-STEM interested girls and aspirations because they are perceived by these girls as particularly unobtainable (Betz \& Sekaquaptewa, 2012). To attract women into this field it is suggested that work need to be undertaken to open popular perceptions of the science and the culture that operate within the science to render them more accessible for nontraditional group (Archer et al., 2013).

Heilbronner (2013) notes, that promoting interest in STEM in young students especially girls would be a way to increase women's self-efficacy in STEM domains. Lack of self-efficacy in STEM continues to be an influential factor in women misrepresentation in this area and that teacher may help talented girls develop high self-efficacy through providing specific praise directed towards efforts rather than ability, teach that abilities are not fixed but rather developed and teach realistic goal setting (Dweck, 2007; Halpern et al., 2007). Ifegbesan (2010) also stated that when stakeholders are made aware of their gender biased behavior/practices and provided strategies to combat bias and better able to promote gender equity in the classroom and society. The author recommends that teachers should avoid language that limits one gender to another from participating in the classroom interaction and should learn to be selective in their language. Ifegbesan (2010) also states that gender-natural labels such as chairperson and head teachers should be encouraged in social engagement and that there is need to change the socialization process of gender within our schools which ensures that girls are made aware that they are unequal to boys. Those activities such as making boys the class captain and girls assistant should be revised this enables both party to see themselves as being equal.

There is need to redesign curriculum in education to include a course regarding gender-equality (Erden, 2009; Ifegbesan, 2010). This appears to be very needful since the establishment of gender equality and fair educational environment requires teachers who hold unbiased gender beliefs and that are conscious of gender issue (Ifegbesan, 2010). Syllabus designers and curriculum developers must also make room for the gender of the prospective teachers, learners and topic within the target socio-cultural context as influential factors in determining the quantity and quality and nature of classroom interaction (Rahimpour \& Yaghoubi-Notash, 2008). In doing this, the authors maintain that the language teaching practioners need to be duly attentive to gender which may affect or even obscure interaction in certain ways leading to biased judgment of leaner's performance on the teacher's part.

Ferrara (2009) acknowledges that when planning and developing instructional materials, teachers should ensure a balance in teaching styles to match the various learning style of the students in their classroom as a step to combat this bias. Existing textbooks should be revised to take into cognizance of the gender issue (Ifegbesan, 2010). The objective of FME (2004) is equal access of men and women to education, therefore young women and men should have access to technical an vocational education and on the job training as is essential prerequisite for women to obtain higher skill and better paying jobs. Wirth (2002) states that until a sufficient number of women have the qualifications and skills required for moving into "men's" job they cannot constitute the critical mass in organization needed to ensure that all women not just the exceptional few have the chance to advance.

There is no doubt Nigeria is a fast growing economy and competitive participant in the world market. However, in order for Nigeria to sustain economic growth, it requires a skilled local labor work force educated in various area of TVE and sciences. Women need to be encouraged to enroll in technical and vocational education and nontraditional subjects and in areas of future job growth. Wirth (2002) posits that young men need to increasingly prepare to understand the changing gender roles and the implication for their own professional social and family lives.

Jones \& Chant (2009) asserts that education and employment policies should not only aim to reduce gender discrimination in schools and the labor market, but also attempt to address gender inequalities within home. One of the main barriers according to Jones \& Chant (2009) is that young women's enrolment in schools and access to employment owes to social expectations that women should perform the bulk of reproductive labor in their youth as well as adulthood. The authors note that couple with discrimination against girls and women within and beyond the family, the tendency is for men to end up with more educational qualifications, more skill and higher-paying jobs even if unemployment among young people in general remain a major problem.

Mutekwe et al., (2011) notes that gender role socialization coupled with teacher attitudes, parental expectations and the influence of peers as well as learner's subject combinations have an enormous impact on the learner's resultant career trajectories. Gender role socialization girls and boys tend to acquire early beliefs about their social roles and thus have been found to exert significant influence on their education and career aspirations and choice. Jones \& Chant (2009) suggests that parents should be encouraged to value their girl children on a par with boys and should attempt to equalize domestic reproductive labor burden at all stages of the life course.

Abimbade (2008) observed that the knowledge of information technology will help in facilitating female participation in technical and vocational education, since it has become a potent force capable of transforming social, economic and 
political life of people globally. The author further stated that if the access to and use of information technology is directly linked with the study of technical and vocational education, it will attract female attention and ginger their participation in this field. Students' enrolment decisions anticipated success and sense of belonging are significantly shaped by the design of the virtual educational environment. When a computer science virtual classroom reflected current masculine stereotypes women's intention to enroll in the class and their anticipated performance increased to the level of the male peer (Cheryan et al., 2011). This simple design change had a profound effect. The author states that the implication is that the physical design of learning environments, such as classroom, workshops, computer labs and departments can project identity-based message about who does not belong and thereby deter some population from entering the field and believing they cannot achieve success there. Study show that non-stereotypical virtual classroom environment increased women's interest, anticipated success and sense of belonging in computer science over a neutral classroom that had on stereotypical on non-stereotypical objects in it. Therefore, institutions should strive to design virtual environment to improve student learning (Cheryan et al., 2011).

\section{The Present Study}

\subsection{Design of the Study}

In qualitative research design can be thought as the logical progression of stages or tasks from problem formulation to the generation of conclusions that are necessary in planning and carrying out a study (Maxwell, 2008). Ritchie \& Lwis (2013 p.47) state that is one which has a clearly defined purpose in which there is coherence between the research question and the methods which generate data that is valid and reliable. It gives direction from the underlying philosophical assumptions to research design and collection. Yin (2003 p.19) adds further that colloquially a research design is an action plan for getting from here to there, where 'here' may be defined as the initial set of questions to be answered and 'there is some set of conclusions. Bogdan (2003) states that it is the entire process of conceptualizing a problem to writing research question and data collection, analysis, interpretation and reporting.

When the understanding of an event is a function of personal interaction and perception of those in that event and the description of the process that characterize the event, qualitative approach is more appropriate than quantitative design to provide the insight necessary to understand the participants' role in the event and their perceptions of the experience. The purpose of this study is to explore without the manipulation of the experience of Nigerian women in male-dominated technical and vocational education in the natural setting with the view to interpreting phenomena in terms of the meaning individuals attach to them.

The processes of this study method included investigating, observing and documenting in detail the unique experience of individuals in the male-dominated technical and vocational education. The approach allowed the researcher to collect 'thick narrative description of the phenomenon under study and gave the researcher the opportunity to take into account the views expressed by the participants and important detail of group interactions and multiple interpretations in the group's natural environment. This qualitative description of their experiences and an inductive analysis of data is most appropriate for the purpose of this research because all these procedures enhanced the possibility for some kind of objectivity which could have been lost if quantitative or experimental strategies were applied (Onwuegbuzie \& Collins, 2007)

\subsection{Sampling}

Sampling for this study was driven by the desire of the researcher to learn in detail and in-depth about the experience of individuals. Purposeful sampling is appropriate for use when the author needs to select a sample based on his knowledge of the population, its element and the nature and purpose of the research aim (Creswell, 2012). In this study fourteen women were used in accordance with Merriam (2014) who suggested that in phenomenological research five to twenty five participants are accepted. Merriam maintains that the small sample size will enable researcher to have an in-depth understanding of the study phenomenon and not seek statistical generalization. The criteria used to select study participants are that they have to be women in technical and vocational education, they must have attended primary school for six years, attended a junior secondary school for three years, attended a senior technical college or senior secondary school for three years, have Ordinary National Diploma (OND) certificate in technical and vocational education field from government approved/recognized institution both within and outside the country, have had at least one year work experience before returning to the institution for Higher National Diploma (HND) in technical and vocational education and must be in the first or second year of HND

\subsection{Data Collection}

Through semi-structured in-depth interviews the researcher attempted to get information about the experience of Nigerian women enrolled in technical and vocational education as to why the misrepresentation of women in technical and vocational education at the Polytechnic institution. The open-ended question adopted afforded an opportunity for both the researcher and the participants to discuss some topic in more detail. The researcher invited the participants to tell him their experience in this field. As the discussion progressed the researcher adopted counseling skill conversations as well as paraphrasing, probing and reflection to develop the discussion in line with the research objective (Martin, 2013). Subsequently, the researcher conducted fellow-up interviews to either elaborate or confirm emerging themes and categories and their meanings. 


\subsection{Data Analysis}

The qualitative hermeneutic data analysis was used for this study. Data analysis involves examining of people's words and trying to make explicit the knowledge that is in them (Pope et al., 2000). Analysis of the participants' open-ended responses formed the basis for interpreting and finding meaning from the participants experiences. The process of data analysis commenced when the researcher finished his first interview. The analysis of data in qualitative research is a hand-on process that requires the researcher to commit fully to understanding what the data say. The data collected in this study were analyzed inductively and continuously during and after each collection of data. Qualitative researcher constructs a picture which takes shape as he/she collect and examines the parts. The most suitable model for data collection and analysis is one that interweaves them from the beginning (Maguire, 2008). The data analysis for this study involved examining, sorting, categorization, evaluating, comparing, synthesizing and contemplating the coded data as well as reviewing the raw data and recorded data. The author adopted eight steps suggested by (Hennie, 2009 p.98) as a guide in coding his data.

Even though the model portrays step-by-step procedures, in practice all the procedures work simultaneously..." and the author kept doubling back for more collection and coding" (Jones, 2011). The basic strategy the author adopted was to constantly compare the data gathered. The author conducted an interview, made field notes, reviewed document of one incident, and then later compared it to another incident either the same set of data of different set. This led to the formation of tentative categories, which were compared to each other, and also to other instances. The flexible nature of this model resulted in the development of tentative categories and themes. However, the coding and categorizing were finalized only towards the end of the data collection

Data for this study were collected and constantly analyzed as they came in until the eight focus group and seventh one-on-one interviews were conducted and there was no more new information and no new themes or categories had emerged. According to Creswell (2012) this point is called the saturation point where there was no more new information or insights that can be found from the data, the data collection was stopped as saturation has been attained or reached.

\section{Findings}

Most participants were not familiar with government and institutional policies with regards to ways of attracting women into technical and vocational education program. However, one participant noted that their recommendations will be based on their experience in their journey in technical and vocational education. Among the themes that emerged in the recommendations are gender role, curriculum review, equal opportunity and award of incentives.

\subsection{Gender Role}

The participants in this study stated that while girl/young women are educated they should be told in practical terms the obstacle they will encounter while undertaking a career in TVE and other technical programs. In doing this, it will enable girls/young women to prepare themselves for the challenges they are going to encounter. Some participants stated that while they were in secondary school, were counselors existed that they were made to understand that female students were not suppose to go for professional courses like STEM and that these courses were meant for boys. They expressed that female students were tailored towards the arts or social science oriented courses. There are some female students who may have interest of enrolling in any technical and vocational education and other technical programs but because they were not properly counseled towards technical and vocational education courses they were made to change their mind. The participants commented that females need to have confidence in what their desires are and that they should not allow people to pull them down or talk them out of their dream. One participant had this to say: "Go in with confidence and do not deter in attaining your life goal". Another participant stated; "Do not let anyone tell you that science course is hard and it is better for boys". Participant N8 recalled her experience in the secondary school while trying to choose her career and aligned it to some of the problems some girls encounter while making a career choice in secondary school and stated:

I remember my teacher in my senior secondary school class who was not encouraging to any girl going into any technical course or science related course because he felt it was not good for girls. He made us to understand that it will be too hard for us, but like me when I wrote my West African Examination Council (WAEC) I had a good result in my science subjects and he tried to discourage me from going into any of these technical programs. I finally made it into this course. So I would advice that let nobody discourage you from going into technical and vocational education or science related courses in higher institution of learning. There is no doubt it is male dominated but it does not mean you cannot do it because you are a woman

A participant in her own recalled how she looked towards her friend for help when she wanted to enroll in technical and vocational education course because her parents wanted her to go for something else other than technical and vocational education program:

There was no engineer in my family. We had people in other disciplines like lawyer, doctor and pharmacy. The only person that was there for me was my uncle, who said I should go for whatever course I wanted to do and that I should ignore everyone else. I also remember my good girl friend during my secondary school 
that was in the university and she helped me out when I wanted to make my choice.

She was very supportive

The impression as expressed by participants is that when girls/you women are aware early enough of some challenges they were going to encounter in technical and vocational education field they will prepare themselves. Some of the participant's notion is that because most girls/young women were socialized to believing that technical and vocational education is a male domain. It became necessary for early gender role consciousness to prepare them for technical and vocational education and other technical related programs

\subsection{Curriculum Review}

Some of the participants posit that the present curriculum of TVE is not at par with the industrial needs of the country and also lack international standard. The participants maintained that it is not producing the critical skills needed in today's technological work environment and recommended that the curriculum be reviewed so as to meet the industrial best practice. Apart from reviewing the TVE curriculum at the higher education level some participated advocated the need to restructure the syllabus right from the primary school to include technology classes. They said many girls are not in technical and vocational education program because they missed the foundation from the beginning. According this study participant if girls were exposed to early technology program many girls will indicate interest in the program

However, participant N13 made reference to what appears to play down on the certificate they acquire today in TVE as she has this to say:

The technical and vocational education curriculum should be revisited periodically so as to meet the needs and global trend. When you graduate these days with technical and vocational education certificate and you find yourself in employment, you are made to undergo a retraining which implies that the certificate we obtain in this field in not meeting the industrial needs. I think the institution and those responsible for curriculum planning should try to review the curriculum from time to time to meet the needs of Nigerian industries.

Participant N5 shared her experience during her Industrial Training (IT) which she says calls for curriculum review. According to the participant what is happening in the labor market requires periodic review of the curriculum in every discipline but particularly in technical and vocational education field. This is what this participant has to say:

When I was accepted in Anambra Motor Company Enugu for my Industrial Training (IT) there were so many things I did that were out of the syllabus we operate in my area. What they did on my arrival was to deploy me to their training school for a short period of training because I was only expected to acquire one year industrial training before returning for my Higher National Diploma (HND). I think the industry should liaise with vocational technical education institutions to design the curriculum so that on employment we are not subjected to another round of academic exercise.

The researcher took up the issue of curriculum with one of the Head's Department who told the researcher that the industries are accusing them of not producing technical personnel's needed in today's work environment. However, they are making efforts in this direction to see that the curriculum meets the needs of Nigerian economy and global best practices.

\subsection{Improve Physical Facilities}

Some participants emphatically stated that the physical and learning facilities are in poor conditions and requires urgent attention so as to improve on the learning. They made mention of dilapidating infrastructures that are abound in the institution. Some participant made reference to situation in some classrooms and lecture halls pinpointing that there are no sufficient seats to go round the students. They also cited some of the workshop they are unable to carry out practical work because of inadequate learning materials. One participant said it is a terrible situation and has lead many of the students spending their little resources on procuring some learning material that were supposed to be provided by the school. These participants in their views in order to attract women into technical and vocational education physical and learning facilities have to be provided.

One of the participants in scoring the importance of learning and physical facilities in addressing misrepresentation of women in male-dominated technical and vocational education sated: "For the school to attract women into vocational technical education all necessary facilities have to be in place though you can't get everything but some facilities have to be there. We have studio but no equipment to work with. A very good drawing studio should have equipment to work with but they are lacking".

Participant N4 maintained the need to have good learning facilities to attract women into technical and vocational education field:

The overall physical facilities are not satisfactory. More lecture halls and classrooms need to be built and equipped. If you go to lecture halls and classrooms you will find that they are overcrowded. Some students do not find space to seat on. This is very common in general course where we take courses with other students outside our department. In order to secure a seat you have to be in the lecture room early enough. Some students even hang on the window and others sometimes outside the 
classroom while lecture is going on. With this kind of situation there can be no effective learning. As a lady when we meet this kind of situation one becomes helpless. However, you have to struggle if not you will be left out.

The researcher visited some lecture areas and saw thing for herself. As pointed out by the participants there is an urgent need to address the issue of facilities. Many of the lecture rooms visited are in poor condition and are impediment to smooth academic activities. At the workshops visited not practical activities was witnessed. (Appendix E). The researcher tried to find out from one of the HOD's on the lack of learning facilities. His claim is that efforts are been made to address the situation and handed to the researcher a copy of a request letter for fund forwarded to the school authority (Appendix F).

\subsection{Equal Opportunity}

Majority of the participants expressed that they should be given opportunity like their male counterparts in maledominated technical and vocational environment. According to the participants they should believe in them that they can equally do what the men are capable of doing. Since they all go through the same training and acquire the same technical skill they should give them the opportunity to perform, they should not think that it is the men that can do it. Participant N11 stated:

The lecturers and work supervisors should treat all of us equally. They should allow us to fully participate in the practical work. They should see us as the same with the males. We went through the same system and a situation where they treat us because we are women will not encourage other women to come into this program. What they are saying is that women are not needed in the program. They should allow us to carryout our practical work by ourselves not instructing us to give our work to the guys to do it for us.

One participant stated that "we are not asking for any preferential treatment as women but if given the same opportunity we will prove ourselves that we are equal to the men". Another participant said to attract women into male-dominated technical and vocational education environment "the culture in this field has to change. Women should be given the opportunity to perform because they think we don't know much as the men".

\subsection{Encouragement}

Many other suggestions made by the participants as what to action to be taken to address misrepresentation in maledominated technical and vocation are as follow:

Government should encourage women by creating more jobs for the few women in the program on graduation; this will encourage other women to enroll in the program.

Scholarship should be created for women interested in TVE course. It will attract more women to come into the program.

There should be TV sensitization. Women in TVE should be aired in TV, Radio and other print media for other women and young girls to see, as it will motivate them into enrolling into TVE courses.

Women should be given the opportunity to put into practice the knowledge acquired in this field as it will serve as encouragement to others

Excursion for female students to industry/organizations where they can see women in this field, it will encourage them to enroll in the program. There should be special hostels for technical and vocational education students. It will aid the women to learn more and bring them together.

There should be visual drawings in strategic positions to attract women.

When asked of the advice they have for the girls desiring to come into technical and vocational education, the participants made the following suggestions.

Girls should take their science course serious in secondary school. The teachers should try to make mathematics and science subjects a fun so that more girls will develop interest in this area.

Girls should look for forerunners in technical and vocational education, those who have succeeded in this field to encourage them

\section{Discussion}

\subsection{Gender Role}

Some participants for this study expressed that girls/young women while in secondary school should be told in practical terms the barriers they will encounter while undertaking a profession in TVE and other technical related fields. This they said will enable girls/young women to equip themselves and brace up for the challenges. Many participants expressed dissatisfaction with teachers/counselors as they were not properly counseled on the prospects in technical and vocational education. They participants stated that in most cases where counselors existed that the girls were tailored into nontraditional programs with the belief that it was the female domain or better done by women. According to these study participants this has accounted for very few women in TVE program in higher institution of learning.

This conforms to study which revealed that factors that influence the study of TVE subjects in secondary schools was shortage or absence of guidance counselors. It is found that most schools in Nigeria do not have guidance and 
counselors as a result, most women that are skilled and have the abilities for the TVE were not counseled to study subjects that they would do better in (Azubuike, 2011). It is significant to note as pointed out by some participants that where counselors were available female students were in most cases persuaded into enrolling in social science courses with the belief that they fit in better. In Lufkin et al., (2008) study it was found that young people who have chosen a nontraditional career path often cite a teacher who provided them with the encouragement they needed to be successful in the field.

Teachers and counselors play an essential role in nurturing student's interest towards the subjects taught. Teachers and counselors are they key elements in the education process of these girls. Teachers and counselors have to educate these girls/young women without biases or prejudice. It is the beliefs of study participants that quality counseling and services be made available to women to enable them make career choice in the field of TVE and other related technical programs.

\subsection{Curriculum Review}

Some of the participants posit that the present TVE curriculum is at par with the industrial needs of the country and also lack national standard. The participants also noted the current curriculum is not producing the critical skills needed in today's technological work environment. Some participants narrated their work experience which they claim do not align with what is found in their technical and vocational education syllabus and recommended for curriculum review.

Study has shown that many countries are for a more flexible workforce with high skills (Ngure, 2013). In developing countries today graduates need to be prepared for the world of work so they can function in a range of profession. The inadequate in preparation for the job market brought workplace challenge to participants for this study. The essence of the curriculum reform or review as recommended by the study participants is to provide education for human resource development that will meet the needs of the social, economic and political development of the country. The integration system of the pathway should be adopted where key players in TVE industry will draw up curriculum that meets the labor market demand and the economy. Participants are of the view that Nigeria has to be fully launched into the industrial age especially now that TVE preparedness has become increasingly paramount. This is in line with Chinonso (2010) who advocate that focus now should be on the development of a viable natural system of TVE program that will have easy access and exist with learning pathways, which must be validated by accredited learning that will lead to work or continued progress along the pathway.

The participants for this study noted that the misrepresentation of women in vocational technical education and other STEM field is because girls are not exposed to technology early enough at the primary school level and at home. We have seen a rising concern on lacking of number of female students in science and TVE in recent year. Technical and vocational education and technical related courses are often regarded not attractive by female students. To address this problem early in the development of the children as noted by the participants, there is the need to encourage girls to take science courses from primary school by reforming our curriculum to accommodate this. There is increasing body of study which shows that children have long been recognized as young scientists in the way they explore and try to make sense of their environment. Young children are also young engineers in the sense that they modify the world to satisfy their own need and wants (Mishra \& Yadav, 2013). Therefore, early educators can take advantage of activities that already occur in most early children's classroom (such as building unit blocks) to nurture young children's developing abilities in engineering and design, as well as provide new activities)such as ramps and pathways) that push young children to further develop their engineering abilities (Katehi et al.,2009).

Katehi et al., (2009) also note that young children can create, solve problems, experiment test, adopt, collaborate, and explain - in short, they can participate in the design process as young engineers. It implies that to attract women into TVE, the key focus of the curriculum should be how to increase opportunities for pupils/students at early stage to learn inquiry-based approaches. School science should move from teacher-guided, inquiry-based teaching method in order to engage pupil/students interest (Minner et al., 2010). If teachers adopt activity based approach to science which consisted of different activities for the all round development of children at the elementary level it will enhance girls achievement in sciences that will lead to interest in vocational technical education and STEM fields.

\subsection{Improve Physical Facilities}

Many of the participants for this study attributed the poor physical facilities in TVE as among the factors inhibiting women for accessing and participation in this program. It is the opinion of some participants that for women to be attracted into TVE program there is need to have good learning facilities. This is in line with OKwori (2004) who noted that lack/insufficiency of teaching materials constitute a major impediment to success in technical and vocational education. He further stated that female pupils showed negative attitude to primary science and TVE because they were not exposed to a variety of relevant teaching materials like their male counterparts.

The negative attitude of science and technical and vocational education expressed by primary school female pupils is developed at the early ages. Hoffmann-barthes et al (1997) indicated that the proper use of educational facilities in teaching technical and vocational education will determine whether women will have equitable access to technical and vocational education. Additionally, many participants stated that because of the inadequate learning facilities in the classrooms, workshops and laboratories they were made to spend their own money on procuring materials that were supposed to be provided by the institution or government and this according to study participants are barriers to women participation in TVE program. Flowers (1995) study has recommended that to attract women into technology education there is need to provide clean high technology classroom and laboratories versus shops. 


\subsection{Equal Opportunity}

Finding of this study suggests that Nigerian women in technical and vocational education generally face discouraging experience while working with their male colleagues. It is found from this study too that women participated less and lost confidence and competent. Participants expressed that the unequal treatment in the academic and work environment is because of their status as women. The participants indicated that being a woman hindered their participation in TVE environment. In the academic and work environment, participants experienced unequal treatment and lower level of trust and confidence resulting in fewer opportunities for them to show their competency. The participants suggest that women unfair treatment in male - dominated technical and vocational environment will improve if their number is substantially increased and their status as women eliminated.

These experiences of unequal treatment of Nigerian women in TVE, in which issues are clearly at play, highlight the efforts that are made by some men to point out those women in technical an vocational education program, are simply not welcome. The entrenched stereotyping in technical and vocational education clearly makes women feel they are being excluded, isolated and generally unwelcome. This unequal treatment of women in TVE impedes their full participation in this field, it may undercut not only academic and work environment meritocracy, but also the expansion of the technological workforce needed for the next decades advancement of national competitiveness (Moss-Racusin et al.,2012).

\subsection{Encouragement}

Many of the study participants have put forward suggestion that stakeholder in technical and vocational education should do to encourage women to enroll in the program. The participants expressed opinion that the misrepresentation of women in this field is because women are not encouraged. The study participants noted that if women are encouraged many of them will come into the program. Among suggestions made by the study participants that could encourage women into TVE program include provision of job opportunities, scholarships and women sensitization in the program could promote more women access and participation in this field. Furthermore, participants also suggested that provision good infrastructural material will encourage women as well as using the few women in the field as a source of role model.

The suggestions advanced by study participant on encouragement of women to access and participation in TVE program is in line with many studies in this area. Hoffmann-barthes et al., (1997) report show that in order to encourage women into TVE there should be employment of opportunities for women in TVE program. Similarly, in a study by Rosser \& Zieseniss (2000) have also recommended the recruitment/more opportunities as a way of encouraging women to enroll into engineering/science programs. In the same vain study by Gomile-chidyaonga (2003) on encouraging greater enrollment of women in science and technology suggested that government, educational institution and stakeholders should begin with the socio-cultural framework and proceed to dispel the myths assumptions and beliefs that have prevented women from access and participation in this field. The author has also recommended the award of scholarships to girls in nontraditional programs. Studies also show that the visible presence of women in the field will provide encouragement for women considering a major in technical and vocational education program.

\section{Conclusion}

It is established in this research that technical and vocational education is a vital force for development and that the non participation of girls/women in this field rob them of the opportunity to improve their lives and contribute maximally to national development. Even though remarkable efforts have been made by the Federal Government of Nigeria through its political commitment and educational programs at ensuring gender equity in technical and vocational education program, the government as matter of urgency should workout large scale technical and vocational education activities and strategies for promotion of women in this field (John, 2011)

Policy makers and employers not only need to place women education in technical and vocational education in the centre of social and economic policies, they need to recognize that challenges faced by women in technical and vocational education in Nigeria and the world at large require intervention tailored to specific needs. It is along this premise that the author calls for the recognition of peculiar challenges which militate against women participation in technical and vocational education and there should be policy measures to tackle them.

It is only fair and acceptable to say that all people should be given equal educational opportunity irrespective of sex, creed, race and religion. Political pronouncements in many countries across the globe have taken on knowledge and skills as the key aim of the desire to improve access to education at all levels. Given the recent development in which knowledge and skills have become more acceptable in terms in economically more developed nations, in which both are seen to go hand in hand, what is happening in Africa and Nigeria were development in highly sought but has proven to be more elusive.

Many in science and technical and vocational education hold the truth to be self-evident that there should be more women in this field. The author holds that more women should be enrolled into technical and vocational education program. Typical argument, include possible benefit to women and possible benefit to the economy. In light of the growing dominance of science and technology in the shaping of the future of societies, the author advocate for equitable distribution of educational opportunities in technical and vocational in institution of higher learning to avoid wastage of potential female talents. 
Nigeria is a fast growing economy and competitive participant in the world market. In order for Nigeria to sustain its economic growth, it requires a skilled local workforce educated in various areas of technical and vocational education and science. In view of the fact that Nigerian women still remain an untapped potential in the field of technical and vocational education, the higher education institution in the country offering technical and vocational education programs must acknowledge the need to inform and inspire females in senior secondary school to consider the nontraditional career path to technical and vocational education.

The author hopes that the result of this research will contribute to the state wide and national dialogue on gender equity in technical and vocational education and other technical related programs that will lead to new public policies, research initiatives, and educational reforms. Women are expected to make up over half the workforce by 2020 . If we do not address these issue now when will we?

\section{Acknowledgement}

The author wish to acknowledge the assistance of the Rector and Dean, School of Engineering, Federal Polytechnic, Idah, Kogi State, Nigeria, the Dean, Professor Ab Rahim Bin Bakar, Professor Azim B. Hj Hamzah and Assoc. Professor Abdullah Bin Mat Rashid, Faculty of Educational Studies, Universiti Putra Malaysia for their guidance at different stages of this research. The author, also thank the Tertiary Education Trust Fund for the financial assistance to carry out this research.

\section{Reference}

Abimbade, A. (2008). Abimbade, A. (2008). “Technical and Vocational Education for Sustainable Development”. In M. Boucouvalas \& R. Omolewa., Aderinoye (Eds) Education for Mellennium Development - Essays in Honour of Professor Michael.

Archer, L., DeWitt, J., Osborne, J., Dillon, J., Willis, B., \& Wong, B. (2013). "Not girly, not sexy, not glamorous": primary school girls' and parents' constructions of science aspirations 1. Pedagogy, Culture \& Society, (ahead-of-print), 1-24.

Aronson, J., Fried, C. B., \& Good, C. (2002). Reducing the effects of stereotype threat on African American college students by shaping theories of intelligence. Journal of Experimental Social Psychology, 38(2), 113-125.

Azubuike, O. C. (2011). Influential Factors Affecting the Attitude of Students Towards Vocational Technical Subjects in Secondary Schools in Southeastern Nigeria, 1(September), 49-56.

Betz, D. E., \& Sekaquaptewa, D. (2012). My fair physicist? Feminine math and science role models demotivate young girls. Social Psychological and Personality Science, 3(6), 738-746.

Bogdan S., R. \& B. (2003). Qualitative research methods for education: an introduction to theories and methods (4th ed.). Boston: Allyn \& Bacon.

Cheryan, S., Meltzoff, A. N., \& Kim, S. (2011). Classrooms matter: The design of virtual classrooms influences gender disparities in computer science classes. Computers \& Education, 57(2), 1825-1835.

Chinonso, O. U. (2010). Entrepreneurship Development through Technical and Vocational Education for Selfemployment and Youth Empowerment in Africa. International Journal of Learning, 17(5), 575-590

Creswell, J. W. (2012a). Qualitative Inquiry and Research Design: Choosing Among Five Approaches (p. 472). SAGE Publications.

Dar-Nimrod, I., \& Heine, S. J. (2006). Exposure to scientific theories affects women's math performance. Science, 314(5798), 435.

Dweck, C. S. (2007). Is Math a Gift? Beliefs That Put Females at Risk. s Math a Gift? Beliefs That Put Females at Risk. Ceci, Stephen, J. (ED); Williams, Wendy M. (Ed). (2007). Why aren't more women in science? Top research debate the evidence., (pp. 47-55). Washington, DC, US: American Psychological Association, xx, 254

Erden, F. T. (2009). A course on gender equity in education: Does it affect gender role attitudes of preservice teachers? Teaching and Teacher Education, 25(3), 409-414.

Ferrara, M. M. (2009). The student and the teacher-Making a match in a single-gender classroom. Advances in Gender and Education,(1), 14-21.

Flowers, J. (1995). Overcoming the barriers : technology education as a career choice for women Journal of Women and Minorities in Science and Engineering, 2, 17-32.

FME. (2004). Federal Ministr of Education. National Policy on Education. Lagos.

Franks, K. I. M., Schurink, W., \& Fourie, L. (2006). Exploring the social construction of life roles of career-oriented women, 32(1), 17-24. 
Gomile-chidyaonga, F. A. (2003). Encouraging Greater Enrollments of Women in Science and Technology: the Malawi Polytechnic Experience by Encouraging Greater Enrollments of Women in Science and Technology: the Malawi Polytechnic Experience.

Good, C., Rattan, A., \& Dweck, C. S. (2012). Why do women opt out? Sense of belonging and women's representation in mathematics. Journal of Personality and Social Psychology, 102(4), 700-17

Halpern, D. F., Aronson, J., Reimer, N., Simpkins, S., Star, J. R., \& Wentzel, K. (2007). Encouraging girls in math and science. Washington DC: U. S. Department of Education. NCER 2007-2003

Haynie III, W. J. (2003). Gender issues in technology education: A quasi-ethnographic interview approach. Gender Issues, 15(1). Available http://scholar.lib.vt.edu/ejournals/JTE/v15n1/haynie.html

Heilbronner, N. N. (2013). The STEM Pathway for Women What Has Changed? Gifted Child Quarterly, 57(1), 39-55.

Hennie, R. B. (2009). Analysis in Qualitative Research. Sage Publication, Thosand Oaks.

Hoffmann-barthes, A. M., Nair, S., \& Malpede, D. (1997). Scientific , Technical and Vocational Education, (September), 1-42.

Ifegbesan, A. (2010). Gender-Stereotypes Belief and Practices in the Classroom: The Nigerian Post-Primary School Teachers. Global Journal of Human Social Science Research, 10(4), 29-38

John, O. N. (2011). Gender Feminism and the Girl-Child. Journal of Education and Social Research, 1(4), 91-98.

Jones, G. A., \& Chant, S. (2009). Globalising initiatives for gender equality and poverty reduction: Exploring "failure"with reference to education and work among urban youth in The Gambia and Ghana. Geoforum, 40(2), 184196.

Jones, M. (2011). Guiding the use of Grounded Theory in Doctoral studies - an example from the Australian film industry, International Journal of Doctoral Studies, 6, 95-114.

Katehi, L., Greg, P., \& Michael, F. (Eds). (2009). Engineering in the K-12 education. Understanding the states and improving the prospects. Washington, DC: National Academic Press. Early Childhood Eucation and Practice (Vol. 16). Washington, DC: National Academic Press.

Kazmi, W. S. (2007). Vocational Education and Skills Development: A Case of Pakistan. SAARC Jouranl of Human Resource Development, 3(1), 105-117

Lufkin, M. E., Wiberg, M. M., Jenkins, C. R., Berardi, S. L. L., Boyer, T., Eardley, E., \& Huss, J. (2008). Gender equity in career and 421-443. javascript:document.getElementsByTagName('body')[0].appendChild(document.createElement('script')).setAttribute('sr c','https://www.mendeley.com/minified/bookmarklet.js');

Maguire, L. L. (2008). Developing Distance Education Policy Within A State System of Higher Education: The Faculy Perspective. Retrieved from file://C:/Users/dll/Downloads/Dissertation_FINAL.pdf

Martin, P. G. (2013). The experiences of women in male-dominated professions and environments in South Africa. Journal of Industrial Psychology, 39(2), 1-12.

Maxwell, J. A. (2008). Designing a Qualitative Study, 214-253.

Merriam, S. B. (2014). Qualitative Research : Aguide to Design and Implementation. John Wilsey and Sons.

Minner, D. D., Levy, A. J., \& Century, J. (2010). Inquiry-based science instruction-what is it and does it matter? Results from a research synthesis years 1984 to 2002. Journal of Research in Science Teaching, 47(4), 474-496.

Mishra, S. K., \& Yadav, B. (2013). Effect of Activity Based Approach on Achievement in Science of Students at Elementary Stage. GJHSS-G: Linguistics \& Education, 13(4), 716-733

Moss-Racusin, C. A., Dovidio, J. F., Brescoll, V. L., Graham, M. J., \& Handelsman, J. (2012). Science faculty's subtle gender biases favor male students. Proceedings of the National Academy of Sciences, 109(41), 16474-16479.

Ngure, S. W. (2013). Stakeholders' perceptions of technical, vocational education and training: the case of Kenyan micro and small enterprises in the motor vehicle service and repair industry. http://ro.ecu.edu.au/cgi/viewcontent.cgi?article $=1598 \&$ context $=$ theses

OKwori, R. . (2004). Gender inequality in education: The case of female and technology education. Journal of International Gender Studies, (1), 62-71.

Onwuegbuzie, A. J., \& Collins, K. M. T. (2007). A typology of mixed methods sampling designs in social science research. The Qualitative Report, 12(2), 281-316.

Pope, C., Ziebland, S., \& Mays, N. (2000). Qualitative research in health care. Analysing qualitative data. BMJ (Clinical Research Ed.), 320(7227), 114-6.

Raghuram, P. (2008). Migrant Women in Male-dominatedsectorsof the labor market a research agenda. Population, Space and Place, 14(1), 43-57.

Rahimpour, M., \& Yaghoubi-Notash, M. (2008). Examining teacher and student gender influence in task-prompted oral L2 variability. Issues in Applied Linguistics, 16(2), 133-150 
Ritchie, J. \& Lwis, j. (2013). Qualitative Research Practice: A Guide for Social Science Students and Researchs. Sage Publication. Thousand Oaks.

Rodgers, M. Y., Zveglich, E. A., \& Wherry, L. (2006). Gender Differences in Vocational School Training and Earning Premiums in Taiwan. Journal of Feminist Economics, 12(4), 527-560.

Rosser, S. V, \& Zieseniss, M. (2000). Career issues and laboratory climates: different challenges and opportunities for women engineers and scientists (survey of fiscal year 1997 POWRE awardees). Journal of Women and Minorities in Science and Engineering, 6(2), 50-78

Samah, A. A. \& Ndaeji, N. M. (2013). Literacy and Women Empowerment for Sustainable Development in Nigeria. New York Science, 6(8), 104-109.

Uwaifo, V. O. (2009). Industrializing the Nigerian society through creative skill acquisition vocational and technical education programme. International NGO Journal, 4(4), 142-145.

Weber, K., \& Custer, R. (2005). Gender-based Preferences toward Technology Education Content, Activities , and Instructional Methods, 16(2), 55-71.

Wirth, L. (2002). Breaking through the glass ceiling: Women in management. In ILO Working Paper presented at the 1st International Conference Pay Equity between Women and Men. Luxembourg (Vol. 4).

Yin, R. K. (2013). Case Study Research: Design and Methods (p. 312). SAGE Publications. 